Available online at JSJ: Jurnal Studi Jurnalistik

http://journal.uinjkt.ac.id/index.php/jsj

JSJ: Jurnal Studi Jurnalistik, 3 (1), 2021, 48-62

\title{
Unsur Keberpihakan Pada Pemberitaan Media Online Analisis Wacana Kritis Pemberitaan Kampanye pada Kumparan.Com
}

\author{
Azwar \\ azwarsutanmalaka@gmail.com \\ Rizki Pratama Putra \\ rizkipratamauicci@gmail.com \\ Uljanatunnisa \\ uljanatunnisa@upnvj.ac.id \\ Program Studi Ilmu Komunikasi, FISIP, UPN “Veteran” Jakarta
}

\begin{abstract}
Abstrak
Pemilu 2019 menampilkan memanasnya kampanye untuk merebut hati rakyat. Banyak media berlomba mengangkat berita teraktual seputar Pileg dan Pilpres. Dalam kondisi ini, media seharusnya berpihak kepada masyarakat dan bukannya menjadi alat kekuasaan atau kepentingan tertentu. Apakah media Kumparan.com benar-benar netral? Atau malah memihak kepada salah satu paslon. Peneliti melakukan analisis mendalam terkait teks media untuk mengetahui secara jelas dan gamblang makna, ideologi, keberpihakan dan kepentingan media. Tujuannya agar publik dapat menilai dan memilah informasi yang benar. Teori yang digunakan dalam penelitian ini adalah analisis wacana kritis dari Norman Fairclough, sedangkan metodenya adalah deksriptif kualitaif melalui teknik Analisis Wacana Kritis (Critical Discourse Analysis). Hasil penelitian menunjukkan bahwa pemberitaan Kumparan.com berpihak kepada salah satu Paslon Capres dan Cawapres Jokowi-Maruf.
\end{abstract}

Kata Kunci: Berita, Keberpihakan Media, Wacana Kritis

Permalink/DOI: http://doi.org/10.15408/isj.v3i1.19878

\section{Pendahuluan}

Pemilu 17 April 2019 membuat media-media massa berlomba menghadirkan berita-berita teraktual seputar pemilu. Selain itu, media juga menjadi sasaran empuk para kandidat politik untuk menyusupkan unsurunsur kampanye, kepentingan politik, dan ideologi di dalam teks beritanya.
Masa kampanye sejak 23 September 2018 hingga 13 April 2019. Selama masa ini calon dan partai politik bertarung memenangkan hati rakyat. Berbagai cara kampanye dilakukan dari yang normal hingga black campaign. Tidak jarang pula media terlibat di dalam kampanye politik.

Media massa juga dimiliki oleh individu atau kelompok tertentu untuk 
mendominasi kelompok yang tidak dominan. Dominasi dilakukan dengan mempengaruhi publik melalui wacana yang di dalamnya terdapat ideologi yang dibekukan lewat bahasa. Sehingga membuat publik secara tidak langsung terpengaruh dan perlahan dikontruksi realitasnya oleh wacana media. Keadaan ini pun menyebabkan netralitas dan kredibilitas media massa diragukan. Terlebih lagi sebagai suatu alat untuk menyampaikan wacana atau berita tentang apa saja, media memiliki kemampuan untuk berperan sebagai institusi yang dapat membentuk opini publik. Selain itu media juga dapat menjadi suatu kelompok penekan atas suatu ide, gagasan, dan bahkan suatu kepentingan atau citra yang hendak direpresentasikan untuk digunakan pada konteks yang lebih empiris (Sobur. 2009). Media menempati posisi strategis dengan kekuasaan karena kekuatan legitimasinya dan ia menjadi arena pertarungan kepentingan dan ideologi (Louis Althusser dan Gramsci: dalam Sobur, 2009).

Media seharusnya harus berpihak kepada masyarakat dan bukan menjadi alat kekuasaan atau kepentingan tertentu, mendominasi kelompok tertentu, atau pencitraan politik. Ia seringkali disebut sebagai pilar keempat demokrasi atau The Fourth Estate (kekuatan keempat) dalam kehidupan sosial-ekonomi dan politik masyarakat (Sobur, 2009). Oleh karena itu, perlu sebuah analisis mendalam terkait teks media untuk mengatahui secara jelas dan gamblang makna, ideologi, keberpihakan media dan kepentingan media.

Sementara itu media online telah mendominasi pilihan utama pembaca milenial. Hal ini menandai pergeseran budaya membaca masyarakat dari metode konvensional ke digital. Menurut data Kementrian Kominfo, ada 260 juta gadget tersebar di 262 juta orang Indonesia.
Sedangkan menurut Asosiasi Penyelenggara Jasa Internet Indonesia (APJII), lebih dari 50 persen dari jumlah penduduk Indonesia telah terhubung Internet sepanjang 2017 dan 49,52 persen penggunanya adalah orang di usia produktif 19 hingga 34 tahun (tekno.kompas.com). Artinya, teknologi komunikasi modern sudah menjadi primadona yang tidak dapat dipisahkan dalam keseharian masyarakat saat ini.

Setiap platform media online memiliki ciri khas tersendiri terhadap output berita yang disampaikan. Media online sama seperti layaknya media massa lainnya, yakni memiliki anggota redaksi yang menentukan kebijakan pemberitaannya. Proses berita tidak lepas dari kebijakan redaksi media yang akan memunculkan framing tertentu terhadap berita. Dalam hal ini, media dituntut untuk menjaga netralitas terhadap nilai berita, atau cover both side. Namun tidak jarang pula media-media online yang dalam pemberitannya cenderung memihak kepada salah satu objek beritanya.

Salah satu platform media online yang belum lama hadir di Indonesia adalah Kumparan.com. Budiono Darsono, Abdul Rahman, Calvin Lukmantara, dan bersama para mantan karyawan Detik.com, seperti Hugo Diba, Ine Yordenaya, Heru Tjatur, Arifin Asydhad, dan Yusuf Arifin mendirikan startup media online bernama Kumparan.com (id.techinasia.com/kumparan). Portal online ini menawarkan konsep baru, yakni media kolaboratif yang tidak sekadar berfungsi untuk membaca berita, tetapi dapat membuat dan berbagi macam-macam berita dan informasi. Dengan kata lain Kumparan adalah media online yang berkolaborasi dengan media sosial dengan slogan yang unik Redefinition Media, yang berarti mendefinisi ulang industri media digital Indonesia. 
Tidak berbeda dengan media massa lainnya, dalam eforia politik beberapa bulan silam Kumparan.com juga turut memberitakan informasi-informasi terkait pasangan calon presiden dan wakil presiden. Khususnya pada kampanye akbar di stadium Geloran Bung Karno melalui enam berita Jokowi-Ma'ruf dan Prabowo-Sandi di Stadion Gelora Bung Karno (GBK) yang dipublikasikan pada rentang waktu 7 April hingga 13 April 2019. Berita-berita ini dipilih berdasarkan tujuan dan kriteria peneliti. Kriteria yang digunakan oleh peneliti adalah tema berita yang terkait dengan kampanye akbar kedua pasangan calon presiden dan wakil presiden di GBK. Masing-masing berita juga dipilih karena memiliki lawan, atau pada kedua pasangan calon diberitakan dengan tema yang sama. Dari keenam berita ini sudah dipasangkan sesuai dengan kesamaan temanya. Peneliti berasumsi bahwa dari berita yang dipasangkan, terdapat perbedaan wacana antara teks berita yang membahas pasangan Jokowi-Ma'ruf dan Prabowo-Sandi. Hal tersebut secara tidak langsung memperlihatkan adanya keberpihakan, dominasi, dan ideologi dari Kumparan.com.

Berita yang penulis gunakan adalah perbandingan wacana yang terkandung di dalam teks pemberitaan kampanye akbar Jokowi-Maruf dan Prabowo-Sandi pada media Kumparan.com. Isu kampanye akbar kedua pasangan calon cukup masif diberitakan oleh Kumparan.com. Pemberitaan dimulai dari sebelum pelaksanaan kampanye akbar hingga pasca kegiatan. Terhitung dari tanggal 2 hingga 13 April, menurut pengamatan penulis di Kumparan.com terdapat 85 berita yang berkaitan dengan kampanye akbar. Dari sejumlah berita-berita tersebut, penulis memilih enam berita yang dianggap cukup dan relevan untuk mewakili tujuan penelitian. Adapun berita tersebut sebagai berikut:

Tabel 1: Daftar Judul Berita

\begin{tabular}{|c|c|l|l|}
\hline No & $\begin{array}{c}\text { Tanggal \& Waktu Terbit } \\
\text { Berita }\end{array}$ & \multicolumn{1}{|c|}{ Judul Berita } \\
\hline 1 & 9 April 2019, 7.08 WIB & 5 Skenario Kampanye Jokowi Tanggal 13 April di GBK \\
\hline 2 & 8 April 2019, 6.09 WIB & $\begin{array}{l}\text { 5 Fakta Kampanye Akbar Prabowo-Sandi: GBK Memutih } \\
\text { hingga Protes SBY }\end{array}$ \\
\hline 3 & 4 April 2019, 18:06 WIB & $\begin{array}{l}\text { Alumni 212 Bakal Hadir dalam Kampanye Akbar } \\
\text { Prabowo-Sandi di GBK }\end{array}$ \\
\hline 4 & 13 April 2019, 16:26 WIB & $\begin{array}{l}\text { JK, TGB, Yusuf Mansur, hingga Slank Meriahkan } \\
\text { Kampanye Akbar Jokowi }\end{array}$ \\
\hline 5 & 7 April 2019, 07:50 WIB & $\begin{array}{l}\text { Prabowo Sapa Pendukung yang Putihkan GBK: Allahu } \\
\text { Akbar! Merdeka! }\end{array}$ \\
\hline 6 & 13 April 2019, 15:59 WIB & $\begin{array}{l}\text { Ucapkan Salam dari Berbagai Daerah, Jokowi Disambut } \\
\text { Riuh di GBK }\end{array}$ \\
\hline
\end{tabular}

Sumber: Disadur dan diolah dari Kumparan.com

Daftar berita di atas merupakan acuan bagi peneliti untuk menganalisis keberpihakana Kumparan. Com, sehingga 50 | Jurnal Studi Jurnalistik, Vol.3, No.1, 2021 fokus penelitian akan menitikberatkan pada konstruksi bahasa dan produksi makna berita online kumparan.com dalam 
merepresentasikan masalah-masalah sosial. Untuk menjawab fokus penelitian ini peneliti menggunakan analisis wacana kritis. Analisis wacana menurut Labov dalam Darma, (2009) adalah sebuah penggambaran secara rasional terkait hubungan rangkaian yang ada dalam kesatuan yang tersusun, sehingga tampak gamblang hubungan unsur-unsur di dalamnya, di luar kesatuan tersebut, maupun kesesuaiannya. Analisis wacana erat kaitannya dengan studi bahasa. Menurut A.S. Hikam dalam Eriyanto (2011) setidaknya ada tiga pandangan analisis wacana terhadap bahasa sebagai berikut:

1. Pandangan pertama diwakili oleh kaum positivisme-empiris. Menurut aliran ini, bahasa dilihat sebagai jembatan antara manusia dengan objek di luar dirinya. Manusia dianggap dapat mengungkapkan pengalaman, ekspresi, gagasan dan ide melalui perantara bahasa tanpa ada penghalang atau kendala. Dalam jangkauan premis-premis kalimat yang logis, sintaksis, tata bahasa, dan berhubungan dengan pengalaman yang realistis. Intinya adalah penyampaian pernyataan yang logis, baik, dan sesuai kaidah lebih diutamakan ketimbang melihat alasan subjektif yang mendasari penyampaian tersebut. Dan hal ini adalah ciri utama dari aliran positivisme-empiris.

2. Pandangan atau aliran kedua disebut konstruktivisme. Aliran ini banyak dipengaruhi oleh pemikiran fenomenologi. Berkebalikan dengan aliran pertama, pandangan ini justru menganggap penting subjek atau sang komunikator penyampai pesan. Subjek memiliki kontrol langung terhadap pernyataan dan makna yang hendak disampaikan. Setiap pesan atau pernyataan yang dilontarkan memiliki tujuan dan secara tidak langsung bermakna pembentukan diri dan pengungkapan jati diri. Oleh sebab itu, analisis wacana dalam pandangan ini bertujuan untuk memngungkapkan maksud dan tujuan tertentu yang tersembunyi dibalik wacana yang disampaikan.

3. Aliran ketiga disebut juga pandangan kritis. Aliran ini mengkritik pandangan konstruktivisme yang disebut kurang peka terhadap unsur historis dan unsur kelembagaan dalam proses produksi makna dan reproduksi makna dari wacana. Paradigma kritis ini lebih memfokuskan diri dalam menganalisis unsur-unsur kekuasaan dan ideologis di dalam struktur wacana. Individu tidak dianggap sebagai subjek yang bebas nilai dan dapat mengungkapkan pikirannya atau memproduksi dengan sesuka hati. Hal ini karena individu dianggap sangat berhubungan dengan kekuatan makrososial di dalam masyarakat yang otomatis menjadi dasar pertimbangan produksi makna wacananya. Lebih dalam lagi, bahasa disini bukanlah medium komunikasi yang netral, melainkan berperan dalam membentuk identitas individu atau subjek tertentu, tema-tema, serta strategi-strategi kekuasaan. Oleh sebab itu, pandangan ini selalu terlibat dengan konteks hubungan kekuasaan institusional. Dan pandangan ini disebut juga Critical Discourse Analysis (CDA) atau Analisis Wacana berparadigma kritis (A.S. Hikam, dalam Eriyanto, 2011).

Sebuah wacana di dalam Analisis wacana kritis (AWK) tidak dipahami sematamata sebagai suatu studi bahasa. Tetapi bahasa yang dianalisis relatif berbeda dengan studi bahasa dalam pengertian linguistik tradisional. Bahasa yang dianalisis bukan hanya dari aspek kebahasaan melainkan juga 
dihubungkan dengan konteks. Konteks yang dimaksud digunakan untuk tujuan dan praktik tertentu, seperti praktik kekuasaan untuk memarginalkan individu atau kelompok tertentu. Haryatmoko (2017) mengungkapkan AWK tertarik pada cara bagaimana bahasa dan wacana digunakan untuk mencapai tujuan-tujuan sosial, termasuk untuk membangun kohesi sosial atau perubahan-perubahan sosial. wacana merupakan proses dsemiotik merepresentasikan dunia sosial.

Analisis wacana kritis bisa digunakan untuk mengkritisi. Seperti yang di sampaikan oleh Darma (2009) bahwa analisis wacana kritis (AWK) juga digunakan untuk mendeskripsikan sesuatu, menerjemahkan, menganalisis, dan mengeritik kehidupan sosial yang tercermin dalam teks atau ucapan. Selain itu AWK juga berkaitan dengan studi dan analisis teks serta ucapan untuk menunjukkan sumber diskursif, yaitu kekuatan, kekuasaaan, ketidaksetaraan, ketidak adilan, dan prasangka. Darma (2009) menjelaskan bahwa tujuan AWK yaitu untuk mengembangkan asumsi-asumsi yang bersifat ideologis yang terkandung dibalik kata-kata dalam teks atau ucapan dalam berbagai bentuk kekuasaan. Analisis wacana kritis menurut Eriyanto (2011) menggambarkan wacana sebagai praktik sosial menyebabkan sebuah hubungan dialektis di antara peristiwa diskursif tertentu dengan situasi, institusi, dan struktur sosial yang membentuknya. Jadi bisa diartikan wacana yang terkandung sangat bergantung dengan faktor yang ada di sekelilingnya baik yang berhubungan secara langsung maupun tidak langsung.

AWK melihat sebuah bahasa sebagai faktor penting, yakni bagaimana bahasa digunakan untuk melihat ketimpangan yang terjadi. Lanjut menurut Eriyanto (2011) melalui wacana, sebagai contoh, keadaan yang rasis, seksis, atau ketimpangan dari kehidupan sosial dipandang sebagai suatu common sense atau suatu kewajaran yang alamiah dan memang seperti itu kenyataannya.

Analisis wacana kritis memiliki beberapa karakteristik, melalui Van Dijk, Fairclough, dan Wodak, dalam Eriyanto (2011) menguraikan beberapa karakteristik dari analisis wacana kritis sebagai berikut:

1. Tindakan, Eriyanto mengungkpakan bahwa prinsip pertama, wacana dipahami sebagai sebuah tindakan atau action. Pada pemahaman seperti ini mengasosiasikan wacana sebagai bentuk interaksi.

2. Konteks, Guy Cook dalam Eriyanto (2011) menyebut ada tiga hal yang sentral dalm pengertian wacana: teks, konteks, dan wacana. Wacana di sini kemudian dimaknai sebagai teks dan konteks bersama sama.

3. Historis, salah satu aspek penting untuk bisa mengerti teks adalah dengan menempatkan wacana itu dalam konteks historis tertentu. Pemahaman suatu wacana teks hanya bisa dimengerti kalau kita bisa memberikan konteks historis di mana teks itu diciptakan.

4. Kekuasaan, Pada karakteristik kekuasaan analisis wacana kritis melihat kekuasaan itu dalam hubungannya dengan wacana, penting untuk melihat apa yang disebut sebagai kontrol. Satu orang atau kelompok mengontrol kelompok lainnya melalui wacana.

5. Ideologi, Eriyanto (2011) menyebutkan ideologi juga merupakan konsep yang sentral dalam analisis wacana bersifat kritis.

\section{Metode Penelitian}


Metode yang digunakan pada penelitian ini adalah deksripiti kualitatif, dengan teknik pengambilan data menggunakan sumber data primer dan sekunder melalui tiga teknik yaitu dokumentasi, observasi non partisipatif dan metode sampling. Teknik analisis data yang digunakan adalah jenis analisis teks berparadigma kritis, di mana paradigma kritis melihat fenomena sebagai sesuatu hasil konstruksi sosial dan dipengaruhi oleh nilai, dan konteks sosial. Atas dasar ini, akhirnya paradigma kritis melihat media bukan saluran yang bebas nilai atau netral melainkan dimiliki oleh kelompok dan digunakan untuk mendominasi kelompok lainnya. Teknik analisis teks media berparadigma kritis ini bernama Analisis Wacana Kritis (Critical Discourse Analysis).

Penulis menilai metode analisis wacana kritis yang digunakan untuk meneliti pada teks-teks media massa adalah efektif dan menyeluruh. Metode analisis wacana paradigma kritis ini tidak hanya mengamati struktur bahasa secara objektif, tetapi melihat keseluruhan teks, konteks, aspek historikal, intertekstualitas, dan ideologi dalam suatu wacana. Oleh karena itu, analisis wacana kritis sangat cocok untuk melihat unsurunsur dominasi, keberpihakan, idelogi, hubungan kekuasaan, dan kepentingan politis yang terbekukan dalam sebuah wacana.

Penggunaan teknik analisis wacana kritis dengan pendekatan atau model Norman Fairclough. Analisis model ini didasarkan pada cara menghubungkan teks yang mikro dengan konteks masyarakat yang makro. Titik tekannya adalah melihat bahasa sebagai praktik kekuasaan yang digunakan pembuat wacana untuk menyampaikan ideologi yang dibekukan dalam bahasa. Oleh sebab itu, sesuai dengan pendapat Faircloug dalam Eriyanto (2011) analisis harus dipusatkan pada cara bahasa terbentuk dan dibentuk dari relasi dan konteks sosial tertentu.

Model ini sering juga disebut sebagai model perubahan sosial (social change). Analisis Norman Fairclough (dalam Eriyanto 2011) didasari oleh pertanyaan besar, "bagaimana menghubungkan teks yang mikro dengan konteks yang makro. Perbedaan dengan model analisis wacana kritis lain adalah Fairclough membuat kerangka yang berkontribusi pada analisis sosial dan budaya. Titik tekannya melihat bahasa sebagai praktik kekuasaan. Oleh sebab itu, analisis harus ditekankan pada bagaimana bahasa terbentuk dan dibentuk dari relasi sosial dan konteks sosial tertentu. Norman Fairclough memusatkan perhatian analisis wacana kritis dalam tiga dimensi text, discourse practice, dan sociocultural practice.

1. Teks dianalisis secara linguistik, dengan melihat kosakata, semantik, dan tata kalimat.

2. Discourse Practice merupakan dimensi yang berhubungan dengan proses produksi dan konsumsi teks.

3. Sociocultural Practice merupakan dimensi yang berhubungan dengan konteks di luar teks dan konteks.

Tolak ukur atau acuan dasar penulis dalam memlih enam berita itu adalah adanya asumsi keberpihakan, dominasi, dan ideologi di dalam wacana, pada salah satu pasangan calon presiden dan wakil presiden. Asumsi itu berangkat dari pengamatan penulis terhadap wacana-wacana tersebut yang menilai bahwa ada ketimpangan bahasa yang digunakan Kumparan.com dalam memberitakan pasangan Jokowi-Maruf dan Prabowo-Sandi pada kegiatan kampanye akbar di Stadion GBK. Keenam berita tersebut akan dianalis dengan metode Analisis Wacana Kritis model Norman Fairclough yang membagi analisis 
teks menjadi tiga dimensi utama, yakni dimensi teks, praktik wacana, dan praktik sosio-kultural. Menurutnya, pada dimensi teks dapat dilihat dari tiga unsur, yaitu representasi, relasi, dan identitas. Setelah itu, wacana akan dianalisis dengan dua dimensi lainnya. dapat direpresentasikan pada gambar di bawah ini:

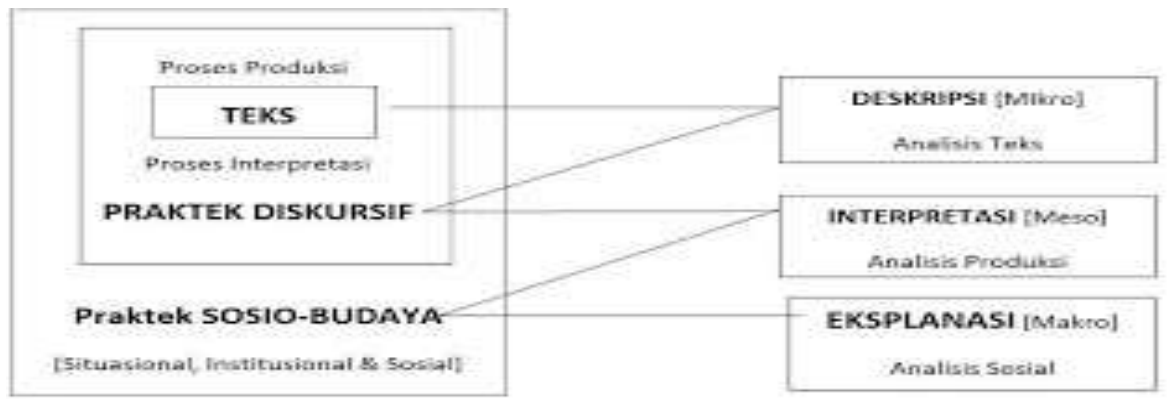

Gambar 1. Tabel Tiga Dimensi AWK Norman Fairclough Sumber:

Haryatmoko (2017)

\section{Hasil dan Pembahasan}

Hasil yang diporeleh bahwa berita yang diterbitkan oleh Kumparan memiliki sejumlah keberpihakan kepada salah satu pasangan calon presiden dan wakil presiden 2019. Keberpihakan itu tercermin dari penggunaan bahasa yang diberitakan Kumparan. Secara eksplisit tidak terlihat bahwa Kumparan berpihak kepada salah satu paslon, namun secara analisis teks menggunakan tiga dimensi Norman Fairclough, terlihat bahwa Kumparan memiliki kecenderungan kepada salah satu paslon. Walaupun Kumparan terlihat untuk memberitakan secara imbang antara kubu Jokowi dan kubu Prabowo.

Sebelum mulai menganalisis, penulis terlebih dahulu mendata seluruh berita yang berkaitan tentang kampanye Prabowo-Sandi dan Jokowi-Maruf di Stadion GBK yang diterbitkan Kumparan pada tanggal 4 April hingga 13 April. Total keseluruhan ada 85 berita dengan 16 tema yang berbeda. Keseluruhan berita ini membantu penulis untuk mereduksi data hingga menjadi unit 54 | Jurnal Studi Jurnalistik, Vol.3, No.1, 2021 analisis yang penulis pilih. Ada enam berita yang penulis pilih untuk dianalisis dengan metode AWK Norman Fairclough. Keenam berita ini secara keseluruhan dipilih karena penulis melihat ada ketidakberimbangan penggunaan bahasa di dalam beritaberitanya. Dari keenam berita tersebut, penulis membandingkan satu berita dengan berita lain yang temanya sejenis.

Berita-berita tersebut adalah:

1. "5 Fakta Kampanye Akbar PrabowoSandi: GBK Memutih hingga Protes SBY" dan "5 Skenario Kampanye Jokowi Tanggal 13 April di GBK" \

2. "Alumni 212 Bakal Hadir dalam Kampanye Akbar Prabowo-Sandi di GBK" dan "JK, TGB, Yusuf Mansur hingga Slank Meriahkan Kampanye Akbar Jokowi"

3. "Prabowo Sapa Pendukung yang Putihkan GBK: Allahu Akbar! Merdeka!” dan "Ucapkan Salam dari Berbagai Daerah, Jokowi Disambut Riuh di GBK" 
Pada analisis berita pertama dan kedua (“5 Fakta Kampanye Akbar Prabowo-Sandi: GBK Memutih hingga Protes SBY" dan "5 Skenario Kampanye Jokowi Tanggal 13 April di GBK"), terlihat bahwa berita yang berisi fakta-fakta tentang kampanye akbar JokowiSandi lebih mengedepankan fakta-fakta yang cenderung menjatuhkan citra kampanye tersebut. Banyak kontroversi yang terjadi antara kumpulan fakta tersebut. Dimulai dari fakta protes SBY, guyon Prabowo terhadap pidato Jokowi, pelemparan botol ke arah Sandi, dan saf shalat shubuh yang bercampur antara pria dan wanita. Dari keempat fakta terlihat jelas semuanya membuat citra negatif terhadap kampanye Prabowo-Sandi.

Sebagai contoh pada dimensi reprsentasi, pada dasarnya ingin melihat bagaimana seuatu direpresentasikan. Pada konteks ini, jurnalis ingin merepresentasikan sejumlah kejadian yang terjadi saat kampanye akbar Prabowo-Sandi kepada khalayak. Dapat terlihat dengan gamblang dari pemilihan kata "5 fakta.." yang digunakan oleh jurnalis. Ia ingin menegaskan kepada khalayak bahwa ada lima kejadian penting dan itu merupakan "fakta" yang terjadi di kampanye PrabowoSandi. Menurut KBBI, fakta adalah sebuah hal (keadaan atau peristiwa) yang merupakan kenyataan dan benar-benar terjadi. Kemudian judul berita dilanjutkan dengan kalimat "GBK Memutih hingga protes SBY."

Penggunaan kata "hingga" disini menjadikan seolah-olah fakta yang dicantumkan pada judul berita adalah pertama dan terakhir, namun di isi beritanya, fakta protes SBY sebenarnya adalah fakta yang kedua. Kata "hingga" menimbulkan makna sebab-akibat. Pada judul, fakta GBK memutih disandingkan dengan fakta protes SBY. Sehingga hal ini bisa bermakna bahwa 55 | Jurnal Studi Jurnalistik, Vol.3, No.1, 2021 memutihnya GBK, pada akhirnya mendapatkan protes dari SBY. Berita dimulai dengan ditunjukkan foto-foto shalat subuh berjamaah yang menjadi awal kegiatan kampanye akbar Prabowo-Sandi. Kemudian dijelaskan tokoh-tokoh penting yang ikut hadir di kegiatan tersebut, yaitu Gubernur DKI Jakarta Anies Baswedan, Rhoma Irama, Wakil Ketua DPR Fadli Zon, dan Habib Rizieq Shihab lewat video conference dari Kota Makkah, Arab Saudi. Selanjutnya, jurnalis memaparkan kelima fakta yang terjadi di kampanye tersebut, fakta-fakta itu adalah:

1. Stadion Utama GBK (SUGBK) Memutih

2. SBY protes konsep kampanye Prabowo-Sandi yang tidak lazim dan terkesan eksklusif

3. Prabowo berguyon menirukan Jokowi berpidato

4. Sandi kaget dilempari botol di panggung kampanye

5. Saf salat subuh bercampur antara perempuan dan laki-laki beredar di media sosial

Pertanyaan utamanya adalah kenapa harus kelima fakta ini yang disajikan oleh jurnalis, sedangkan pasti banyak fakta-fakta lain yang terjadi pada saat kampanye berlangsung. Hal ini berkaitan dengan erat bagaimana jurnalis ingin merepresentasikan dan menggambarkan kampanye akbar Prabowo-Sandi kepada khalayak melalui fakta-fakta yang tersaji di dalam berita. Pada wacana berita ini, jurnalis ingin menggambarkan bahwa kampanye akbar Prabowo-Sandi memiliki banyak kontroversi. Direpresentasikan dengan fakta kedua, empat, dan lima. Fakta kedua, memiliki intensitas tinggi dalam pemberitaan. Apalagi SBY merupakan pimpinan dari Partai Demokrat yang menjadi partai koalisi 
Prabowo-Sandi. Ketika pihak internal sendiri yang mengkritik sebuah kebijakan internalnya, maka hal ini menjadi menarik untuk dibahas oleh media dan tentu saja menjadi poin minus untuk kubu PrabowoSandi. Begitu pun dengan fakta keempat dan kelima. Fakta ketiga menggambarkan Prabowo yang secara terang-terangan mengkritik gaya berpidato dan wacana pidato Jokowi."'Kalian mau dengar pemimpin politik Indonesia memberi sambutan?' tanya Prabowo. Saudara-saudara sekalian, ekonomi Indonesia baik, pertumbuhan lima persen. Lima persen, ndasmu!' teriak Prabowo disambut riuh pendukungnya. Tampak ikut tertawa para pimpinan parpol dan ulama yang berada di belakang Prabowo." "Nanti rakyat akan kita bagi-bagi kartu-kartu. Bung, kita butuh pekerjaan bukan kartu. Betul?" pungkas Prabowo

Berbeda dengan berita yang membahas tentang lima skenario kampanye JokowiMaruf, berita tersebut secara keseluruhan menunjukan bahwa kampanye Jokowi-Maruf dapat diikuti oleh seluruh lapisan masyarakat. Skenario tersebut mencitrakan secara positif kampanye Jokowi-Maruf dengan kata-kata yang positif pula. Seperti seringnya penggunaan kata "keberagaman" yang disandingkan dengan kampanye Jokowi, dan disebutkannya secara rinci fitur-fitur seperti konser musik, hiburan, seniman dan artis, festival kuliner, yang mana ini menjadi pembeda dari kampanye kubu PrabowoSandi. Relasi yang terbangun adalah dari kelima skenario tersebut telah membangun kesan bahwa kampanye JokowiMaruf lebih baik dari kampanye Prabowo-Sandi. Identitas yang terbangun adalah untuk pencitraan pasangan calon kubu 01 dengan kata-kata "keberagaman". Misalnya pada berita ini merepresentasikan bagaimana kampanye 56 | Jurnal Studi Jurnalistik, Vol.3, No.1, 2021 akbar Jokowi-Maruf digambarkan di dalam teks. Penulis telah mengamati dan mencari di tanggal setelah 13 April 2019 dan tidak menemukan berita yang berisi fakta-fakta mengenai kampanye akbar Jokowi-Maruf seperti yang terdapat pada kampanye akbar Prabowo-Sandi. Berita ini dipilih karena dinilai memiliki kemiripan dengan data berita satu, yakni berita yang mengkompilasikan beritaberita menjadi sebuah berita dengan judul yang baru. Berita ini berisi kegiatan kampanye akbar Jokowi-Maruf di GBK, empat hari sebelum pelaksanaannya dimulai. Paragraf sebelumnya menjelaskan bahwa berita ini memiliki kesamaan dengan data berita pertama, namun dengan pemilihan kata yang berbeda, yakni "skenario". Skenario dalam KBBI bermakna rancangan penyelenggaraan sebuah acara atau kegiatan. Hal ini menunjukkan bahwa jurnalis ingin mengungkapkan rencana-rencana yang dibuat oleh kubu Jokowi-Maruf dalam penyelenggaraan kampanye akbar tanggal 13 April 2019.

Pada awal pembukaan paragraf berita, jurnalis menggambarkan kampanye akbar Jokowi-Maruf sebgai acara yang bisa diikuti oleh seluruh masyarakat dari berbagai golongan, suku dan agama. Dikutipnya pernyataan Arya Sinulingga, juru bicara TKN Jokowi-Maruf tentang acara kampanye tersebut, menggambarkan hal ini: "Yang pasti keberagaman pada kampanye akbar Pak Jokowi-Kiai Maruf di GBK tanggal 13 besok akan kami tampilkan ya. Intinya kita memastikan acara kita gembira dan semua rakyat bisa terlibat apapun sukunya, apapun agamanya, apapun pekerjaannya, semuanya akan bersatu dengan bersamasama," terang juru bicara TKN Arya Sinulingga, Senin (8/4). Tidak hanya itu, jurnalis juga menggambarkan bahwa acara tersebut hanya 
berisi tentang kampanye, melainkan dilengkapi dengan sejumlah hiburan. Hal itu tersermin di kalimat pembuka yang ditulis oleh jurnalis, “...Tak hanya orasi dari Jokowi dan Ma'ruf, kampanye akan dimeriahkan sejumah hiburan. Mulai dari konser hingga keberadaan festival kuliner."

Pada skenario pertama, jurnalis tampak sedang memperjelas gambaran bahwa acara kampanye Jokowi-Maruf tidak hanya soal kampanye semata, melainkan terdapat fitur hiburan dan akan diselenggarakan secara besar-besaran. Terlihat dari kalimat "Kampanye akbar Jokowi-Ma'ruf dinamai 'Konser Putih Bersatu..." Lalu ditambahkan dengan pernyataan Erick Tohir yang menggambarkan bahwa kampanye Jokowi akan dilaksanakan secara masif, "Konser itu akan digelar besar-besaran. Saya tidak mau bicara angka. Pastinya, ini akan menjadi pesta penutup kampanye terbuka paslon 01 yang sangat luar biasa. Kami di TKN berharap dengan pentas musik ini, sekaligus penutup kampanye, masyarakat memasuki masa tenang dan bersiap menuju ke TPS pada 17 April untuk mencoblos nomor urut 01," kata Erick pada Selasa (2/4).

Pada fakta kedua, jurnalis kembali menggambarkan bahwa kampanye JokowiMaruf akan benar-benar menghibur dengan akan hadirnya 500 artis tanah air yang diantaranya musisi, band, dan seniman. Hal itu tercermin dari kalimat, "Selain kampanye, acara akan diisi oleh konser yang digagas sejumlah musisi, seniman, dan relawan yang tergabung dalam gerakan \#BarengJokowi. Di antaranya grup musik Slank, musisi Addie MS, penyanyi Memes, komedian Arie Kriting, hingga mantan perenang nasional Richard Sam Bera. Inisiator konser, Abdee Negara, menuturkan setidaknya

57 | Jurnal Studi Jurnalistik, Vol.3, No.1, 2021 ada 500 artis, musisi, seniman dan budayawan yang akan hadir."

Pada skenario ketiga, jurnalis kembali memperjelas gambaran kampanye JokowiMaruf yang memiliki banyak fitur menarik. Menampilkan skenario bahwa kampanye tersebut akan dilengkapi dengan festival kuliner. Hal ini tercermin pada kalimat, "Kampanye Jokowi-Ma'ruf juga akan dimeriahkan oleh festival kuliner nusantara..." Didukung oleh pernyataan Sekretaris Jenderal Partai Golkar Lodewijk Paulus yang secara detil mengatakan, "Tanggal 13 itu (areanya) dibagi tiga ring. Ring pertama dalam GBK. Ring kedua itu di luar GBK dalam pagar, sebelum jalan. Dan ring Ketiga pada jalan. Ring pertama akan difungsikan untuk panggung utama kampanye akbar. Sementara ring kedua untuk area festival kuliner nusantara. Lalu, di ring terluar, diatur untuk menampung para kader partai koalisi (PDIP, Golkar, PKB, PSI, Perindo, PPP, PBB dan Hanura). Pada ring tiga nanti juga akan menghadirkan para kader partai, mulai nanti dari Bundaran Hotel Indonesia sampai nanti ke Patung Pemuda Senayan. Kemudian seputaran dari GBK, itu dari Semanggi kemudian terus ke TVRI, TVRI kemudian ke hotel Mulia, Asia Afrika, sampai ke Hotel Century, " rinci Lodewijk."

Kendala konsumsi saat acara-acara yang melibatkan massa yang masif merupakan hal yang lumrah. Pernyataan Lodewijk soal festival kuliner dan rincian posisi-posisinya seolah telah memecahkan kendala konsumsi dan menjawab keresahan masyarakat yang mungkin ingin mengikuti acara tersebut. Disebutkannya skenario bahwa akan ada festival kuliner dan posisinya yang akan menjangkau seluruh peserta kampanye hingga ke luar stadion membuat peserta yang ingin mengikuti tidak 
perlu takut akan kendala konsumsi. Apalagi festival tersebut bertajuk

"Festival Kuliner Nusantara", yang menambah nilai jual dari kegiatan tersebut.

Pada skenario keempat, terlihat bahwa sub-judulnya terasa tidak pas apabila disandingkan dengan kata "skenario". Kalimat subjudul itu adalah, "TKN Optimistis Massa Lebih Banyak 3 Kali Lipat dari Kampanye Prabowo". Kalimat sub-judul itu dinilai tidak sesuai dengan padanan kata skenario apabila merujuk pada judul utama berita. Kata optimistis pada kalimat "TKN Optimistis..." menurut KBBI adalah kata sifat yang bermakna bahwa TKN optimis terhadap sesuatu. Kata optimis mensifatkan TKN. Keoptimisan dalam konteks ini bukanlah bagian dari skenario kampanye JokowiMaruf, melainkan hanya menggambarkan sifat dari TKN, yang dalam hal ini terkait dengan jumlah massa yang akan menghadiri kampanye tersebut. Kemudian hal ini ditegaskan dan didukung pula dengan pernyataan Muhaimin Iskandar atau Cak Imin, "Jumlahnya akan tiga kali lipat, akan lebih gede," ucap Cak Imin optimistis usai menghadiri acara Majelis Taklim Bersholawat di Istora Senayan, Jakpus, Senin (8/4)."

Pada skenario kelima, jurnalis menulis sub-judul dengan kalimat, "380 Ribu Orang Sudah Daftar Ikuti Kampanye." Kalimat ini merupakan pernyataan yang bersifat pemberitahuan bahwa telah ada 380 ribu orang yang mendaftar untuk mengikuti kampanye akbar Jokowi-Maruf. Apabila dikaitkan dengan kata "skenario" seperti judul utama berita, maka hal ini tidak sesuai karena sub-judul hanya bersifat memberitahukan suatu hal dan tidak menagndung unsur rencana atau strategi. Angka 380 ribu dinilai sudah melebihi dari kapasitas stadion GBK. Terlihat dari 58 | Jurnal Studi Jurnalistik, Vol.3, No.1, 2021 pernyataan Abdee, "Dari panitia mungkin yang akan hadir sepertiganyalah. GBK itu jumlah penonton normalnya sekitar 120 ribu orang dengan kepadatan 4 orang per meter. Kalau terpakai semua sudut mungkin 150 ribu orang," tutur Abdee. Hal ini menunjukkan bahwa angka 380 ribu berarti telah melebihi target dari kapasitas stadion, dengan kata lain peserta akan sangat membludak. Apalagi ditambah dengan kata “...Sudah Daftar...”yang berarti ada peserta yang "belum" mendaftar dan berkemungkinan akan mendaftar.

Kemudian pemberitaan mengenai kehadiran alumni 212 yang akan mengikuti kampanye Prabowo juga membuat kampanye Prabowo-Sandi terkotak. Seolah-olah jurnalis ingin menggambarkan keeksklusifan kampanye Prabowo-Sandi yang hanya diperuntukkan untuk mayoritas muslim. Misalnya saja pada analisis relasi, dimana proses relasi jurnalis menggambarkan bahwa ada hubungan antara alumni 212 dan Anies Baswedan dengan massa yang akan hadir di kampanye Jokowi-Maruf. Mereka berdua dinilai akan menjadi amnusi utama untuk memasifkan peserta kampanye. "(Selain itu) hampir seluruh yang hadir di 212, hadir di sini. Insyaallah hadir, dan "Ia berharap, kegiatan kampanye yang dilakukan pada hari libur, bisa memperbesar kemungkinan Gubernur DKI itu untuk datang ke kampanye Prabowo-Sandi. Anies Baswedan selaku Gubernur Pemerintah Provinsi (Pemprov) DKI Jakarta akan juga menjadi daya tarik bagi peserta yang hadir. Namun kegiatan kampanye tidak disampaikan secara detil oleh wartawan, "Kampanye Prabowo-Sandi di Stadion GBK nantinya akan diisi dengan beberapa kegiatan." Tidak seperti berita kampanye Jokowi-Maruf yang dengan detil disampaikan dan diuraikan oleh wartawan. 
Sedangkan pada dimensi identitas wartawan menggambarkan identitas alumni 212 sebagai massa pendukung PrabowoSandi. "Alumni 212 Bakal Hadir dalam kampanye Akbar Prabowo-Sandi di GBK." Alumni 212 itu sendiri adalah sekelompok massa yang berkumpul pertama kali saat demonstrasi dugaan penistaan agama oleh Gubernor Basuki Tjahja Purnomo (ahok) pada tahun 2016. Massa itu tetap melakukan serangkaian pertemuan rutin apabila ada isuisu yang bersifat nasional maupun internasional. Namun keberadaan kelompok ini juga mendapat penilaian pro dan kontra di masyarakat, dan bahkan ada yang menganggap bahwa massa alumni 212 itu radikal karena banyak ditunggangi oleh massa Front Pembela Islam (FPI) yang terkenal memiliki citra buruk di sebagian masyarakat. Pemilihan judul yang memasukkan langsung kata "alumni 212" secara tidak langsung memberikan cap atau simbol kepada massa kampanye akbar Prabowo-Sandi sebagian besar adalah alumni 212. Apalagi disitu tidak disebutkan massa dari kelompok-kelompok lainnya dan pernyataan yang dikutip oleh wartawa mendukung hal tersebut. Sehingga masyarakat dapat menganggap bahwa massa Prabowo-Sandi hanya dari golongan sebagian besar alumni 212 Berbeda dengan berita kampanye Jokowi-Maruf yang menyebutkan hampir secara keseluruhan tokoh-tokoh dan kelompok-kelompok yang akan hadir.

Sebaliknya pemberitaan di kubu Jokowi menyebutkan secara rinci siapa saja tokohtokoh yang akan hadir di kabinet Jokowi, seperti JK, Yusuf Mansur, TGB, dan Slank. Pada kampanye Jokowi-Maruf direprsentasikan kampanye Jokowi-Maruf dihadiri oleh tokoh-tokoh penting dan cukup dikenal di masyarakat, terlihat dari judul 59 | Jurnal Studi Jurnalistik, Vol.3, No.1, 2021 beritanya, "JK, TGB, Yusuf Mansur hingga Slank Meriahkan Kampanye Akbar Jokowi." Judul berita tersebut juga menunjukkan bahwa tokoh-tokoh itu tidak hanya berasal dari tokoh agama saja, tetapi juga ada tokoh politik, dan bahkan tokoh musisi yang namanya sudah tidak asing lagi didengar oleh masyarakat. Selain itu, digambarkan pula bahwa kampanye ini banyak elite-elite partai politik yang hadir, adapun pada dimensi relasi, seolah-olah Kumparan.com menggambarkan bahwa adanya hubungan yang terbangun antara Jokowi dan elite-elite partai politik yang mengusungnya. Hubungan ini terlihat baik dan terjaga dikarenakan kehadiran mereka di dalam kampanye JokowiMaruf dan tidak ada keributan atau konflik internal seperti SBY pada Prabowo.

Sedangkan pada identitas terlihat identitas Jokowi sebagai orang yang diusung oleh koalisi partai politik dan didukung oleh banyak orang. Identitas Jokowi sebagai calon presiden dan petahana yang senantiasa mendapatkan dukungan tergambar dalam kalimat jurnalis, “Dalam sambutannya, Jokowi berterima kasih kepada seluruh elite parpol pendukungnya, hingga relawan atas berbagai upaya mereka mendukung paslon 01.” Berita juga menunjukkan identitas Jokowi yang mendominasi, diperlihatkan dengan tidak adanya kutipan pembicaraan Ma'ruf Amin dan jajaran elite atau tokoh-tokoh lainnya, melainkan hanya Jokowi saja

Pada berita kelima dan keenam juga digambarkan identitas Prabowo dan Jokowi. Pada berita kelima digambarkan Prabowo sebagai pemimpin yang memiliki nilai islam militan dan radikal. Hal ini tercermin dari penggunaan takbir untuk menyapa pendukungnya, yang mana takbir merupakan simbol agama Islam. Pemilihan kata pada judul ini juga mengesankan keeksklusifan 
kampanye Prabowo yang terkesan bahwa pendukungnya hanya dari golongan muslim. Hal ini dikarenakan kata-kata takbir merupakan identitas umat islam, khususnya dalam konteks ideologi partai dan budaya partai politik. Hal ini juga dipertegas dengan kutipan Prabowo, "Di panggung Prabowo menghampiri mikrofon. "Allahu akbar...! Allahu akbar..!! Allahu akbar..!! Merdeka..!! Merdeka..!! Merdeka...!!" ucap Prabowo menuai sahutan dari massa pendukung."

Sedangkan pada dimensi relasi, terdapat hubungan antara tokoh pejabat politik, tokoh partai politik dan tokoh agama dengan Prabowo-Sandi sebagai pendukung. Terlihat di dalam kalimat, "Hadir dalam acara itu Prabowo dan Sandi, Gubernur DKI Jakarta Anies Baswedan, dan pimpinan parpol, ulama, serta tokoh pendukung 02." Kehadiran mereka di dalam kampanye PrabowoSandi menunjukkan dukungan mereka secara eksplisit. Namun, jurnalis tidak menyebutkan dengan rinci, siapa saja nama-nama yang hadir di dalamnya. Sehingga hal ini menimbulkan kesan bahwa tidak ada tokohtokoh kenamaan yang mendukung Prabowo-Sandi. Pada berita ini, terdapat identitas Prabowo yang digambarkan seolaholah sebagai pemimpin umat islam. Terlihat dari kalimat Prabowo yang menyerukan takbir kepada pendukungnya, yang mana takbir adalah seruan untuk umat islam. Tetapi setalah kata takbir, Prabowo juga mengucapkan kata "merdeka", yang mana kata seruan ini ditujukan untuk semua orang. "Allahu akbar..!! Allahu akbar..!! Allahu akbar..!! Merdeka..!! Meredeka..!! Merdeka...!!”, ucap Prabowo menuai sahutan dari massa pendukung."

Di lain sisi, Jokowi digambarkan sebagai seoarang yang memiliki identitas 60 | Jurnal Studi Jurnalistik, Vol.3, No.1, 2021 yang toleran dan adil. Tercermin dari penggambaran peristiwa Jokowi yang mengucapkan salam dari beberapa daerah di Indonesia. Pada berita ini jurnalis merepresentasikan sebagai pemimpin yang toleran. Hal ini terlihat dari kalimat judul beritanya, "Ucapkan Salam dari Berbagai Daerah. Jokowi Disambut Riuh di GBK." Ucapan salam dari berbagai daerah membuat Jokowi dikesankan sebagai pemimpin yang menghargai keberagaman. Hal ini sesuai dengan skenario awal kampanye akbar Jokowi-Maruf yang mengedepankan keberagaman.

Pada dimensi relasi antara massa pendukung, ratusan artis, budayawan, tokoh agama, dan seniman. Hubungan yang digambarkan oleh jurnalis adalah bahwa mereka semua mendukung Jokowi maju sebagai presiden kembali. Juga digambarkan hubungan ini membuat Jokowi terlihat sebagai pemimpin yang memiliki toleransi tinggi terhadap keberagaman. Begitupula dengan dimensi identitas, jurnalis menuliskan identitas Jokowi sebagai calon presiden yang menjunjung tinggi keberagaman. Ditunjukkan dengan kalimat, "Ia kemudian menyapa para pendukungnya dengan salam dari berbagai daerah" dan ucapan Jokowi, "Sore hari ini saya sangat berbahagiaaaa sekali. Memang negara kita ini adalah negara besar, kuat, yang terdiri dari suku yang berbeda-beda, agama yang berbeda-beda, adat tradisi yang berbedabeda," jelas Jokowi." Identitas Jokowi sebaga calon presiden petahana juga digambarkan sebagai sosok yang berkharisma. Hal ini ditunjukkan dengan kata-kata "disambut riuh" dan "disambut meriah" yang digunakan jurnalis untuk menggambarkan suasana massa pendukung Jokowi. 


\section{Kesimpulan}

Berbagai pemberitaan terkait Kampanye pemilu Pada tanggal 4 hingga 13 April di GBK, masing-masing media khususnya Kumparan juga ramai memberitakan dengan berbagai sudut pandang. Namun dalam pemberitaannya peneliti menemukan keberpihakan Kumparan terhadap salah satu pasangan calon presiden dan wakil presiden. Keberpihakan tersebut didapatkan dengan analisis wacana kritis melalui enam berita kampanye JokowiMaruf dan Prabowo-Sandi.

Jika dianalisis dengan analisis teks, maka akan terlihat bahwa pemberitaan Kumparan berpihak kepada paslon JokowiMaruf. Seperti pemberitaan fakta-fakta Prabowo-Sandi yang berisi kalimat "SBY protes konsep kampanye Prabowo-Sandi yang tidak lazim dan terkesan eksklusif", "Prabowo berguyon menirukan Jokowi berpidato", "Sandi kaget dilempari botol di panggung kampanye", dan "Saf salat subuh bercampur antara perempuan dan laki-laki beredar di media sosial." Semua fakta tersebut membuat citra negatif terhadap kampanye akbar PrabowoSandi.

Sedangkan berita tentang kampanye Jokowi-Maruf, berisi scenario-skenario yang secara keseluruhan membuat citra positif terhadap kampanye Jokowi-Maruf. Seperti "Kampanye akbar Jokowi-Ma'ruf dinamai 'Konser Putih Bersatu...", "Selain kampanye, acara akan diisi oleh konser yang digagas sejumlah musisi, seniman, dan relawan..", "Kampanye Jokowi- Ma'ruf juga akan dimeriahkan oleh festival kuliner nusantara", "TKN Optimistis Massa Lebih Banyak 3 Kali Lipat dari Kampanye Prabowo", dan "380 Ribu Orang Sudah Daftar Ikuti Kampanye.”
Analisis berita selanjutnya, terdapat pengkotakkan yang dilakukan Kumparan terhadap pemberitaan kubu Jokowi. Hal ini terlihat dari judul berita yang berfokus akan kehadiran alumni 212 pada judul beritanya. Sedangkan pemberitaan kubu Jokowi, diberitakan kehadiran sejumlah tokoh-tokoh pentik seperti Jusuf Kalla, Yusuf Mansur, Tuan Guru Bajang (TGB), dan Slank. Bahkan di dalam teks terdapat tokoh-tokoh elite partai politik yang disebutkan namanya hadir di kampanye tersebut.

Selain itu pada analisis berita kelima dan keenam, terlihat Kumparan menegaskan identitas Prabowo dan Jokowi. Pada berita tersebut Prabowo dicitrakan sebagai pemimpin dengan nilai-nilai Islam yang radikal dan militan. Terlihat dari judulnya yang terdapat simbol islam, yakni Prabowo bertakbir kepada pendukungnya, "Prabowo Sapa Pendukung yang Putihkan GBK: Allahu Akbar! Merdeka!" Berita ini juga menegaskan keeksklusifan dari kampanye Prabowo. Berbeda dengan pemberitaan Jokowi yang menegaskan sifat toleransi Jokowi terhadap seluruh masyarakat Indonesia. Tergambar dari judul beritanya, "Ucapkan Salam dari Berbagai Daerah. Jokowi Disambut Riuh di GBK." 


\section{Daftar Pustaka}

Ardianto, E., dkk. (2004). Komunikasi Massa: Suatu Pengantar (edisi revisi). Bandung: Simbiosa Rekatama Media

Aslani dan Salmani (2015). Ideology and Translation : A Critical Analysis Approach Towards

The Representation of Political News in Translation. International Journal of Applied Linguictic \& English Literature, Vol.4, No.3

Assidik dan Santoso (2016). Citra Publik Presiden Republik Indonesia Pada Pemberitaan di Harian Suara Merdeka, Tabloid Tempo, dan Harian Republika: Kajian Analisis Wacana Kritis Model Norman Fairclough. Jurnal Seloka.

Bohang, Fatimah K. (2018, Februari 22). Berapa Jumlah Pengguna Internet Indonesia? Diakses pada April 10, 2019 dari Kompas.com: https://tekno.kompas.com/read/201 8/02/22/16453177/berapaumlahpengguna-internet-indonesia

Darma, Y. (2009). Analisis Wacana Kritis. Bandung: Yrama Widya.

Eriyanto. (2011). Analisis Wacana: Pengantar Analisis Teks Media. Yogyakarta: PT LKiS Group.

Hamad, Ibnu. (2004). Konstruksi Realitas Politik Dalam Media Massa (Studi) Pesan Politik Dalam

Media Cetak Pada Massa Pemilu 1999). Jurnal Makara, Sosial Humaniora, Vol.8, No.1

Haryatmoko. (2017). Critical Discourse Analysis: Landasan Teori, Metodologi dan Penerapan). Jakarta: PT Raja Grafindo Persada.

Ishwara, Luwi. (2015). Jurnalisme Dasar. Jakarta: Kompas.
Junaiyah dan Arifin. (2010). Keutuhan Wacana. Jakarta: PT Grasindo

Mustika dan Mardikantoro (2018). Textual Analysis of Corruption News Text on Trans TV and

Global TV Media: Critical Discourse Analysis by Norman Fairclough. SELOKA: Jurnal Pendidikan Bahasa \& Sastra Indonesia, $173-184$

Putra dan Triyono (2018). Critical Discourse Analysis on Kompas.com, News: Gerakan

\#2019GantiPresiden. LEKSAMA: Jurnal Bahasa dan Sastra, Vol.3, No.2

Romli, Asep S.M. (2012). Jurnalistik Online: Panduan Praktis Mengelola Media Online.

Bandung: Nuansa Cendekia

Sobur, A. (2017). Semiotika Komunikasi. Bandung: PT Remaja Rosdakarya. 